\title{
EVALUATING THE PERFORMANCE OF THE POP- UP SPRINKLER
}

\section{Gomaa, A. H.*，Wasif, E. E.** and El-Sharkawey, A. F.***}

\begin{abstract}
ABSTACT
This investigation was carried out at Faculty of Agriculture, Menoufia University, Egypt, on the Pop-Up sprinkler at operating pressures of $1.5,2$ and 3bar, sprinkler emission angles of $45^{\circ}, 90^{\circ}, 135^{\circ}, 180^{\circ}, 225$ ${ }^{\circ}, 270^{\circ}, 315^{\circ}$ and $360^{\circ}$ and riser heights of $0.15,0.75$ and $1.25 \mathrm{~m}$. Discharge, uniformity distribution, coefficient of variation and water losses percent of the sprinkler due to evaporation and water drift were determined. Results indicated that, when pressure decreases, discharge and coefficient of uniformity decrease. The percentage of the average decreasing for discharge were 28 and $42 \%$ and decreasing of coefficient of uniformity were 12.05 and $23.77 \%$ when using the operating pressures of 2 and 1.5 bar compering with 3 bar resp. But increase coefficient of variation and water loss percent due to evaporation and water drift .Moreover, increasing the riser height at the sprinkler emission angles the discharge and the coefficient of uniformity decrease. When angle increase from $45^{\circ}$ to $360^{\circ}$ the discharge and coefficient of variation increase from 0.115 to $0.362 \mathrm{~m}^{3} / \mathrm{h}$ and from 14.54 to $30.98 \%$ resp. ,while coefficient of uniformity and water loss percent .decrease from 80.46 to $74.38 \%$ and from 17.85 to $11.21 \%$ resp.

Due to interaction between the operating pressure 3 bar and height riser of $0.15 \mathrm{~m}$ at emission angle of $360^{\circ}$ gave the highest value of the discharge, while at the angle of $45^{\circ}$ gave the highest value of coefficient of uniformity.
\end{abstract}

Key words: Discharge rate, uniformity distribution, coefficient of variation and Pop-Up sprinkler.

\footnotetext{
* Pro. Dr. Agr. Eng. Menoufio Uni. , ** Pro. Dr. \& Director of Agr, Eng. Res. Instit. . Dokki, Giza, *** Sen. Res., Agr. Eng. Res. Instit.,Dokki, Giza,
} 


\section{INTRODUCTION}

prinkler irrigation has been one of the most used systems worldwide, mainly due to its operational flexibility and adaptability to different soil, crop and topographic conditions. Morever, the uniformity distribution pattern is a measure of how evenly the sprinkler system applies water over the irrigated area (Zanon, et at ., 2000 ).

Distribution uniformity from an individual sprinkler in simulation, in most cases, is a precipitation linearly decreasing away from the center and is usually assessed on overlapped patterns to help in determining the critical irrigation water requirement (El- Awady et al ., 2003 ).

Keller and Bliesner ( 1990) pointed that, there are several factors affect the water application efficiency of sprinkler irrigation system such as variation of individual sprinkler discharge throughout the lateral lines, variation in water distribution within the sprinkler spacing area .Loss of water by direct evaporation from the spray and evaporation from the soil surface before the water is used by the plants.Also, the sprinkler performance is affected by operating pressure and riser height.

El- Sherbeni ( 1994 ) found that, when riser height increased from 50 to $150 \mathrm{~cm}$, the coefficient of uniformity $(\mathrm{CU})$ values decreased from 78.5 to $70.0 \%$ for Rain Bird sprinkler and from 84.6 to $65.0 \%$ for developed sprinkler under the same operating of $150 \mathrm{kPa}$ and nozzle size $2.4 \mathrm{~mm}$.

ITRC (1991) suggested, the distribution of uniformity ( DU ) values from 65.0 to $75.0 \%$ were good, from 75.0 to $85.0 \%$ were excellent and (50.0$65.0 \%$ were poor for fixed - spray sprinkler and single stream rotor respectively.

The objective of this investigation was to study the effect of pressure, height riser and sprinkler mission angles on discharge, uniformity distribution, coefficient of variation $(\mathrm{Cv})$ and percentage of water loss percent due to evaporation and water drift.

\section{MATERIALS AND METHODS}

Experiments were conducted at Faculty of Agriculture, Menoufia University, Egypt. In this work, three operating pressures $(1.5,2$ and 3 bar), eight sprinkler emission angles $\left(45^{\circ}, 90^{\circ} .135^{\circ}, 180^{\circ}, 225^{\circ}, 270^{\circ}\right.$ 
, $315^{\circ}$ and 360$)$ and three riser heights $(0.15,0.75$ and $1.25 \mathrm{~m})$ were used to evaluate the performance of Pop-Up sprinkler ( Fig. 1 ) .

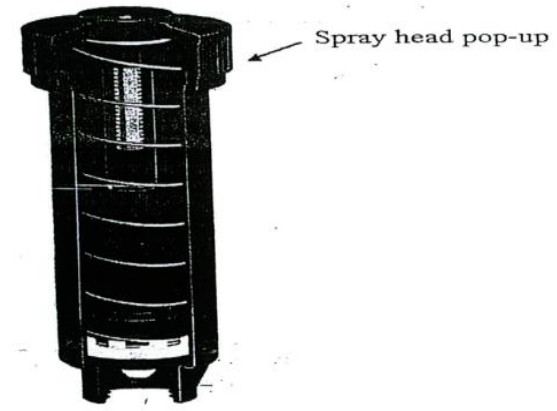

Fig. 1 : Spray Pop-Up sprinkler

Such as flow rate, uniformity coefficient, coefficient of variation and of water loss percent due to evaporation and water drift. Wind speed was measured by using Anemometer through the experiments. Water was collated by using catch cans and the coefficient of Christianson's uniformity was collected by using the following Equation (Christianson's, 1942).

$$
C U=100\left(1-\frac{\sum \mid X_{i-\bar{x} \mid}}{n \bar{x}}\right)
$$

Where

$C U$ : Christiansen's uniformity coefficient, $X_{i}$. : water depth collected by catch cans in mm,

$\bar{X}$ : mean water depth collect in all catch cans in $\mathrm{mm}$ and

$n$ : total number of catch cans.

The coefficient of variation was defined as the ratio of standard deviation to mean water depth, as follows:

$$
\mathrm{CV}=\frac{\mathcal{S}}{\bar{x}}
$$

Where:

$$
\begin{aligned}
& \mathcal{S}: \text { standard deviation and } \\
& \bar{X} \text { : mean water depth . }
\end{aligned}
$$


The sprinkler is operated at a specific time $(\mathrm{mm} / \mathrm{h})$ and the volume of water collected is measured in milliliters by a graduated cylinder. After this experiment, the next step is to analyze the information. It is possible to know the sum of the accumulated depths and the average water depth. The difference between the depth of the water added from the spray and the depth of the water collected in the cans is the water loss percent due to evaporation or water drift.

\section{Effect of pressure:}

\section{RESULTS AND DISCUSSION}

Table (1) and Fig.2 (A, B, C and D) showed the effect of operating pressure and the emission angles of the Pop-Up on the discharge(q), coefficient of uniformity $(\mathrm{Cu} \%)$, coefficient of variation $(\mathrm{Cv} \%$ and water loss percent (L\%). Results indicated that the discharge of the sprinkler decreases by about 28 and $42 \%$ at operating pressure 2 and 1.5 bar compering with 3 bar. Meanwhile, coefficient of uniformity by about 12 and $24 \%$ under the same treatments. Results also showed that, the average values of the coefficient of variation were about 16, 26 and $36 \%$ and the water loss percent were about 11,15 and $17 \%$ under the operating pressure of 3, 2 and 1.5 bar resp.

Table (1 ): Effect of operating pressure and emission angles on discharge coefficient of uniformity, coefficient of variation and water loss percent.

\begin{tabular}{|c|c|c|c|c|c|c|c|c|c|c|}
\hline \multirow{2}{*}{$\begin{array}{l}\text { Pre } \\
\text { ssu } \\
\text { re }\end{array}$} & \multirow{2}{*}{$\begin{array}{l}\text { Paramet } \\
\text { ers. }\end{array}$} & \multicolumn{9}{|c|}{ Emission angles } \\
\hline & & $45^{\circ}$ & $90^{\circ}$ & $135^{\circ}$ & $180^{\circ}$ & $225^{0}$ & $270^{\circ}$ & $315^{\circ}$ & $360^{\circ}$ & mean \\
\hline \multirow{4}{*}{$\begin{array}{c}3 \\
\text { bar }\end{array}$} & $\mathrm{q}, \mathrm{m}^{3} / \mathrm{h}$ & 0.149 & 0.328 & 0.430 & 0.517 & 0.524 & 0.565 & 0.575 & 0.602 & 0.462 \\
\hline & $\mathrm{Cu} \%$ & 90.33 & 88.36 & 86.19 & 84.87 & 83.82 & 82.54 & 80.61 & 79.25 & 84.45 \\
\hline & $\mathrm{Cv} \%$ & 9.67 & 11.64 & 13.81 & 15.13 & 16.18 & 17.46 & 19.39 & 20.75 & 15.55 \\
\hline & $\mathrm{L} \%$ & 12.87 & 12.48 & 11.98 & 11.51 & 11.26 & 10.59 & 10.87 & 9.88 & 11.43 \\
\hline \multirow{4}{*}{$\begin{array}{c}2 \\
\text { bar }\end{array}$} & $\mathrm{q}, \mathrm{m}^{3} / \mathrm{h}$ & 0.114 & 0.243 & 0.339 & 0.345 & 0.358 & 0.467 & 0.491 & 0.520 & 0.332 \\
\hline & $\mathrm{Cu} \%$ & 80.49 & 77.99 & 79.10 & 74.32 & 72.47 & 72.11 & 69.46 & 68.18 & 74.27 \\
\hline & $\mathrm{Cv} \%$ & 19.51 & 22.01 & 20.90 & 25.68 & 27.53 & 27.89 & 30.54 & 31.82 & 25.73 \\
\hline & $\mathrm{L} \%$ & 18.92 & 18.47 & 19.33 & 15.86 & 14.81 & 13.20 & 11.56 & 12.87 & 15.63 \\
\hline \multirow{4}{*}{$\begin{array}{l}1.5 \\
\text { bar }\end{array}$} & $\mathrm{q}, \mathrm{m}^{3} / \mathrm{h}$ & 0.083 & 0.161 & 0.228 & 0.282 & 0.302 & 0.334 & 0.371 & 0.381 & 0.264 \\
\hline & $\mathrm{Cu} \%$ & 70.55 & 68.55 & 67.14 & 63.88 & 63.44 & 61.85 & 60.40 & 59.29 & 64.38 \\
\hline & $\mathrm{Cv} \%$ & 29.45 & 31.45 & 32.86 & 36.12 & 36.56 & 38.15 & 39.60 & 40.71 & 35.62 \\
\hline & $\mathrm{L} \%$ & 21.45 & 20.58 & 18.60 & 17.8 & 16.88 & 15.48 & 14.01 & 14.01 & 17.44 \\
\hline
\end{tabular}




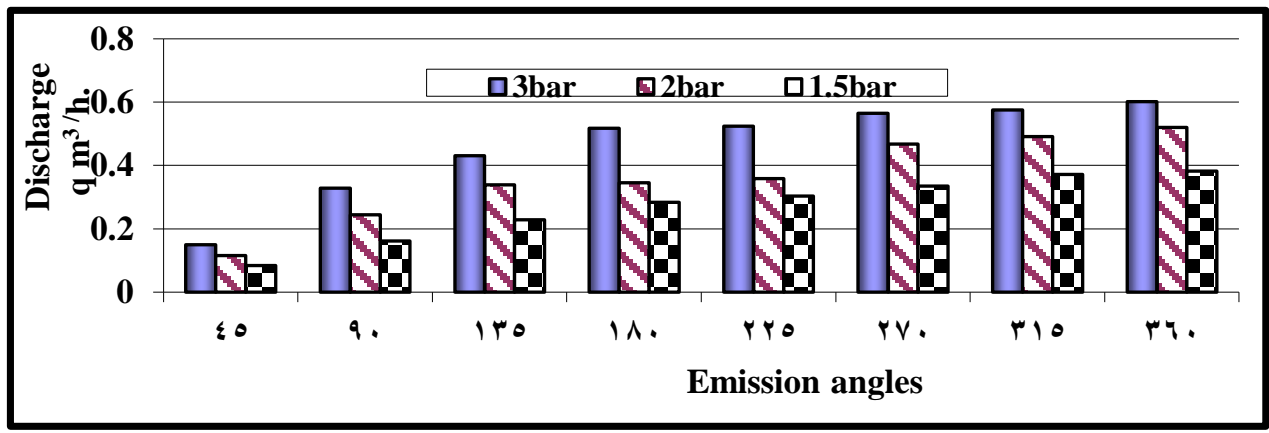

A

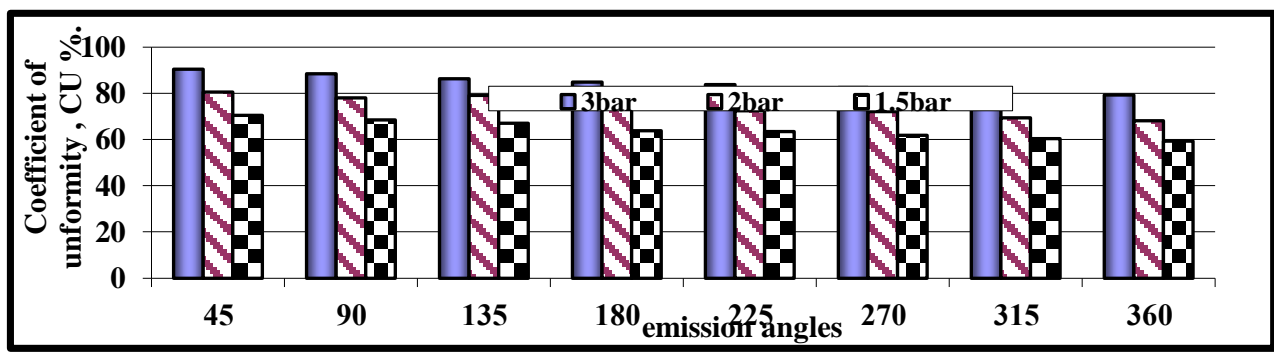

B

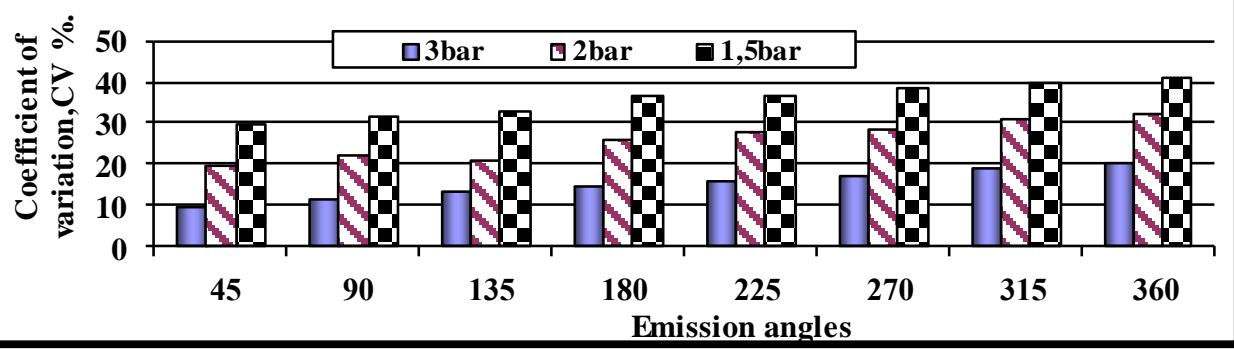

$\mathrm{C}$

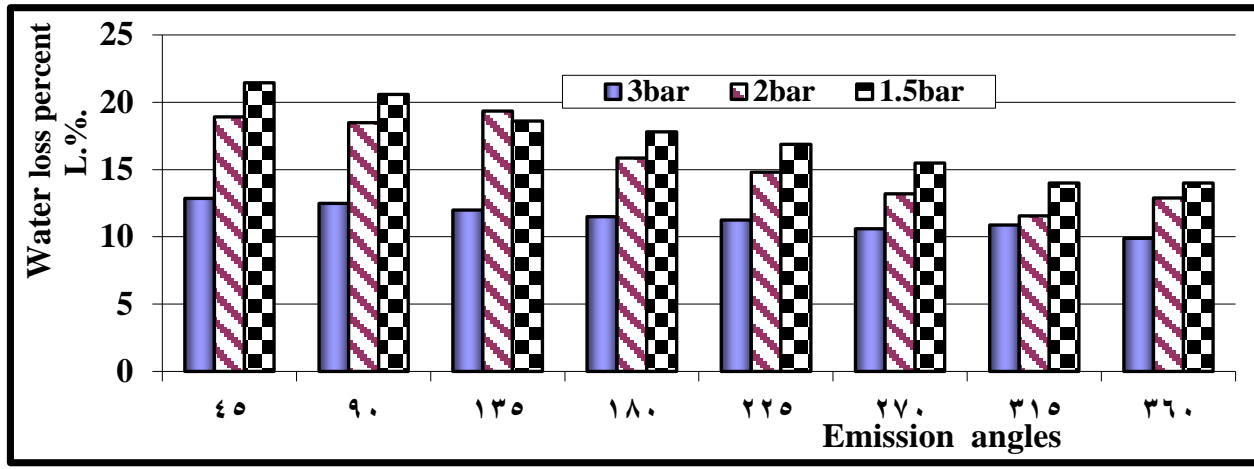

D

Fig. 2.(A,B,C and D) : Effect of emission angles and the operating pressures on studied parameters ( $\mathrm{q}, \mathrm{Cu}, \mathrm{Cv}$ and $\mathrm{L} \%$ ). 
Morever, results showed that increasing the emission angle, increases the discharge of the sprinkler and the coefficient of variation, but decreases the coefficient of uniformity and water loss percent.

\section{Effect of riser height}

Table( 2) and Fig.3.(A,B,C and D) showed the effected of riser height and the emission angles of the Pop -Up on discharge ( q), coefficient of uniformity $(\mathrm{Cu} \%)$, coefficient of variation $(\mathrm{Cv} \%)$ and water loss percent (L \%).

Results indicated that the discharge of the sprinkler decreases, the average values of discharge were $0.381,0.361$ and $0.3450 \mathrm{~m}^{3} / \mathrm{h}$ when height riser increase from 0.15 to 0.75 and $1.25 \mathrm{~m}$. Meanwhile, coefficient of uniformity by $77.97,74.45$ and $71.77 \%$. Data also, showed that, the average of the coefficient of variation were $23.09,25.54$ and $28.27 \%$ and the water loss percent were $9.99,14.89$ and $18.91 \%$ resp.

Table (2 ) :Effect of riser height and emission angles on discharge, coefficient of uniformity, coefficient of variation and water loss percent.

\begin{tabular}{|c|c|c|c|c|c|c|c|c|c|c|}
\hline \multirow{2}{*}{$\begin{array}{l}\text { Riser } \\
\text { height } \\
, \mathrm{m}\end{array}$} & \multirow[t]{2}{*}{ Parameters. } & \multicolumn{9}{|c|}{ Emission angles } \\
\hline & & $45^{\circ}$ & $90^{\circ}$ & $135^{\circ}$ & $180^{\circ}$ & $225^{0}$ & $270^{\circ}$ & $315^{\circ}$ & $360^{\circ}$ & Mean \\
\hline \multirow[t]{4}{*}{0.15} & $\mathrm{q} \mathrm{m}^{3} / \mathrm{h}$ & 0.124 & 0.256 & 0.346 & 0.418 & 0.416 & 0.475 & 0.496 & 0.518 & 0.381 \\
\hline & $\mathrm{Cu} \%$ & 82.69 & 81.13 & 87.89 & 77.76 & 75.71 & 74.34 & 72.57 & 71.66 & 77.97 \\
\hline & $\mathrm{Cv} \%$ & 17.31 & 18.37 & 21.10 & 22.24 & 24.29 & 25.66 & 27.43 & 28.34 & 23.09 \\
\hline & $\mathrm{L} \%$ & 11.49 & 11.33 & 10.74 & 10.22 & 9.73 & 9.23 & 8.84 & 8.35 & 9.99 \\
\hline \multirow[t]{4}{*}{0.75} & $\mathrm{q} \mathrm{m}^{3} / \mathrm{h}$ & 0.115 & 0.240 & 0.326 & 0.380 & 0.393 & 0.454 & 0.477 & 0.499 & 0.361 \\
\hline & $\mathrm{Cu} \%$ & 79.95 & 77.87 & 76.18 & 75.10 & 73.58 & 73.05 & 70.64 & 69.26 & 74.45 \\
\hline & $\mathrm{Cv} \%$ & 20.05 & 22.13 & 23.82 & 24.90 & 26.42 & 26.95 & 29.36 & 30.73 & 25.54 \\
\hline & $\mathrm{L} \%$ & 18.24 & 17.38 & 15.70 & 15.54 & 14.94 & 13.67 & 12.48 & 11.21 & 14.89 \\
\hline \multirow[t]{4}{*}{1.25} & $\mathrm{q} \mathrm{m}^{3} / \mathrm{h}$ & 0.108 & 0.225 & 0.311 & 0.362 & 0.376 & 0.430 & 0.460 & 0.485 & 0.345 \\
\hline & $\mathrm{Cu} \%$ & 78.74 & 75.88 & 74.23 & 72.41 & 70.44 & 69.03 & 67.27 & 66.15 & 71.77 \\
\hline & $\mathrm{Cv} \%$ & 21.26 & 24.12 & 25.77 & 27.59 & 29.56 & 30.97 & 33.03 & 33.86 & 28.27 \\
\hline & $\mathrm{L} \%$ & 23.83 & 22.84 & 20.00 & 19.33 & 18.58 & 16.46 & 15.28 & 15.00 & 18.91 \\
\hline
\end{tabular}




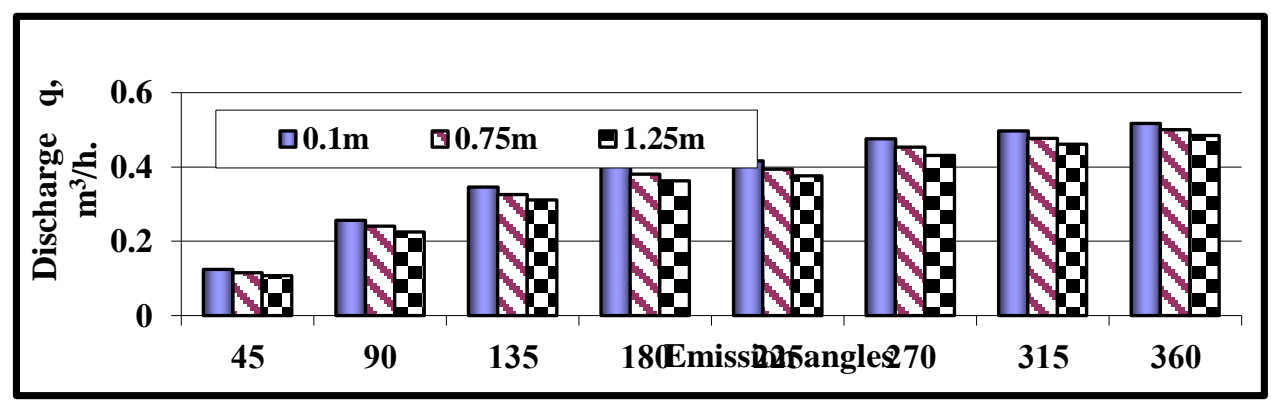

A

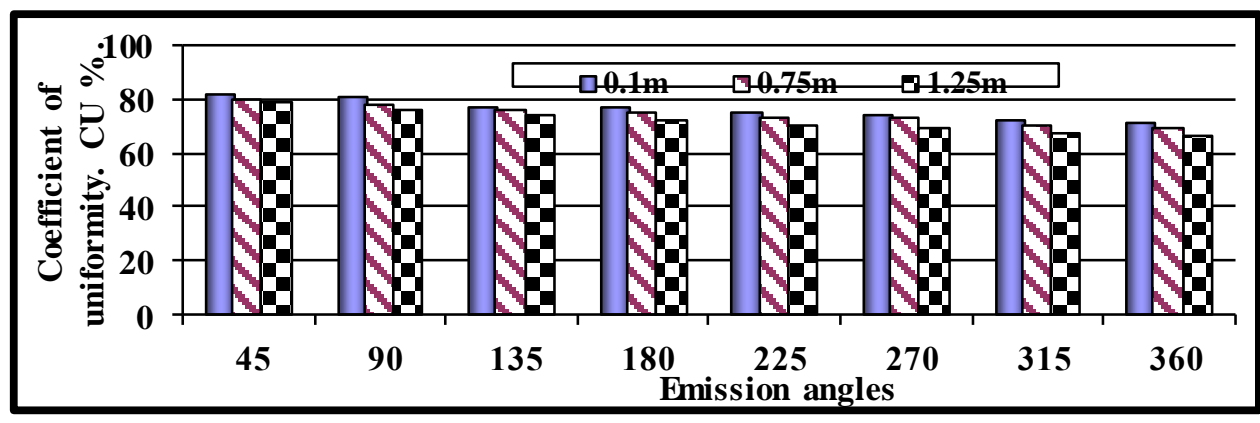

B

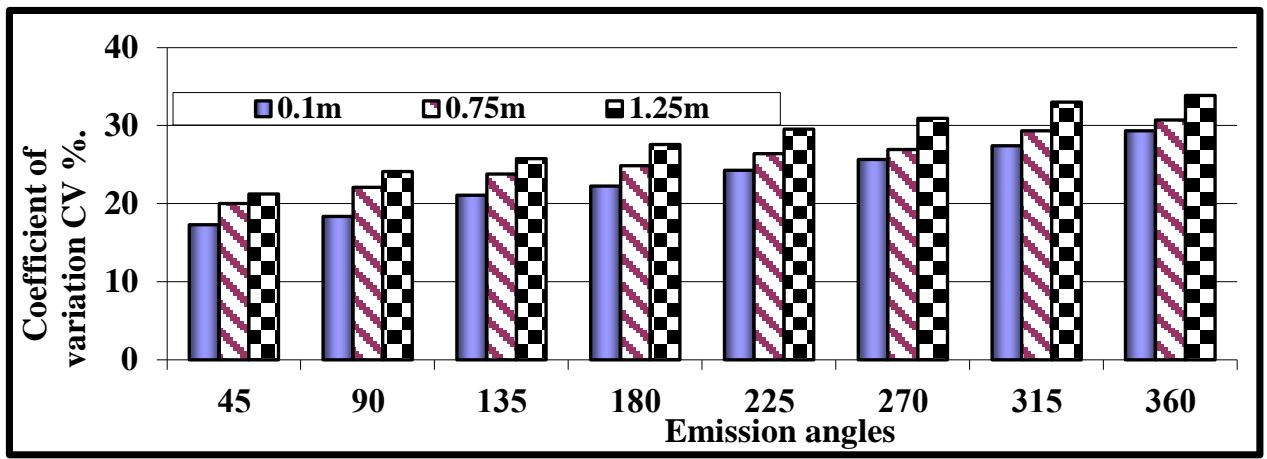

C

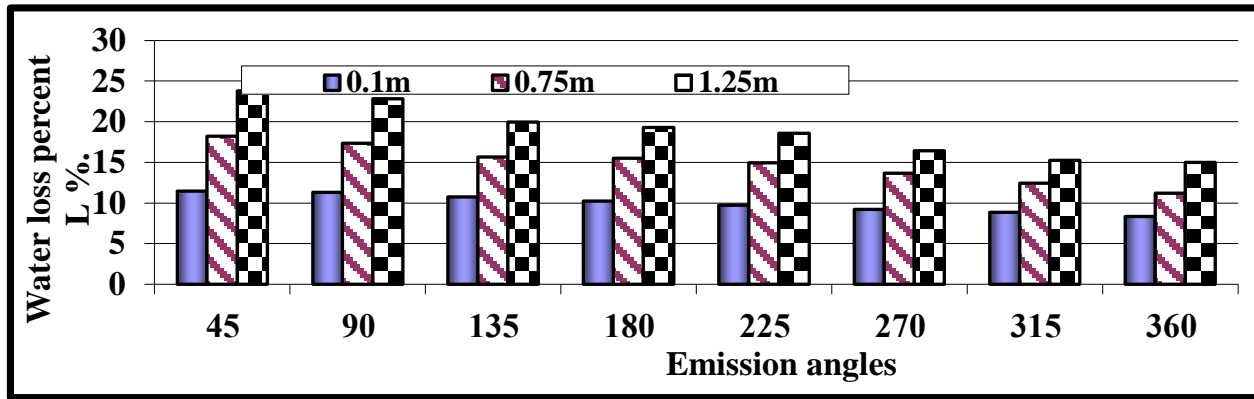

D

Fig. 3 .(A ,B, C and D) : Effect of emission angles and the riser height on studied parameters ( $q, \mathrm{Cu}, \mathrm{Cv}$ and $\mathrm{L} \%$ ). 


\section{Effect of emission angles}

Data in Table ( 3 )illustrated, effect of emission angles on discharge, coefficient of uniformity, coefficient of variation and water loss percent. When emission angle increase from $45^{\circ}$ to $360^{\circ}$ discharge and coefficient of variation increase from 0.1156 to $0.3623 \mathrm{~m}^{3} / \mathrm{h}$ and from 14.54 to $30.98 \%$ respectily, while coefficient of uniformity and water loss percent ( $\mathrm{L} \%$ ) decrease from 80.46 to $74.38 \%$ and from 17.85 to 11.21 $\%$ resp.

Table ( 3 ) : Effect of emission angles on discharge, coefficient of uniformity, coefficient of variation and water loss percent.

\begin{tabular}{|c|c|c|c|c|c|c|c|c|c|}
\hline \multirow{2}{*}{$\begin{array}{l}\text { Para- } \\
\text { meters }\end{array}$} & \multicolumn{10}{|c|}{ Emission angles } \\
\cline { 2 - 10 } & $45^{\circ}$ & $90^{\circ}$ & $135^{\circ}$ & $180^{\circ}$ & $225^{\circ}$ & $270^{\circ}$ & $315^{\circ}$ & $360^{\circ}$ & Mean \\
\hline $\mathrm{q}, \mathrm{m}^{3} / \mathrm{h}$ & 0.115 & 0.240 & 0.327 & 0.386 & 0.395 & 0.453 & 0.485 & 0.362 & $\mathbf{0 . 3 6 2}$ \\
\hline $\mathrm{Cu} \%$ & 80.46 & 78.30 & 76.65 & 75.09 & 73.24 & 72.14 & 70.17 & 74.38 & $\mathbf{7 4 . 3 8}$ \\
\hline $\mathrm{Cv} \%$ & 14.54 & 21.7 & 23.65 & 24.91 & 26.76 & 27.86 & 29.84 & 30.98 & $\mathbf{2 5 . 6 2}$ \\
\hline $\mathrm{L} \%$ & 17.85 & 17.15 & 15.48 & 15.03 & 14.42 & 13.08 & 12.2 & 11.21 & $\mathbf{1 4 . 5 5}$ \\
\hline
\end{tabular}

\section{Effect of interaction}

Data in Table (4) show interaction between 3 bar operating pressure, riser height from $(0.15,0.75$ and $1.25 \mathrm{~m})$ and emission angles from $45^{\circ}$ to $360^{\circ}$ on discharge $\left(\mathrm{m}^{3} / \mathrm{h}\right)$ coefficient of uniformity $(\mathrm{Cu} \%)$, coefficient of variation ( $\mathrm{Cv} \%)$ and water loss percent ( $\mathrm{L} \%)$.

By increasing emission angles under all riser heights at operating pressure 3 bar, discharge and coefficient of variation ( $\mathrm{Cv} \%$ ) increase, due to interaction between pressure 3 bare, riser height $0.15 \mathrm{~m}$ and angle $360^{\circ}$ highest values $0.627 \mathrm{~m}^{3} / \mathrm{h}$. While lowest value $0.141 \mathrm{~m}^{3} / \mathrm{h}$ due to interaction between pressure 3 bar riser height $1.75 \mathrm{~m}$ and emission angle $45^{\circ}$. Meanwhile the highest value $23.00 \%$ of coefficient of variation (Cv) du to interaction between riser $1.75 \mathrm{~m}$ and angle $60^{\circ}$ at 3 bar, lowest value $8.33 \%$ due to riser height $0.15 \mathrm{~m}$ and emission angle $45^{\circ}$.

By increasing angles under all riser heights at 3 bar operating pressure both coefficient of uniformity $(\mathrm{Cu} \%)$, and water loss percent (L\%) decrease, the lowest value $77.00 \%$ and highest value of water loss percent $14.10 \%$ due to interaction between riser height $1.25 \mathrm{~m}$ and emission angle $360^{\circ}$, interaction between riser height $0.15 \mathrm{~m}$ and emission angle $45^{\circ}$ highest value $91.67 \%$ for coefficient of uniformity ( $\mathrm{Cu} \%$ ). But due to interaction riser height $0.15 \mathrm{~m}$ and emission angle $360^{\circ}$ gave 
lowest value $6.00 \%$ of water loss percent ( $\mathrm{L} \%$ ). At the operating pressure, the form of water discharge from the sprinkler will take the form of the straight line so the coefficient of uniformity $(\mathrm{Cu} \%)$ high for the optimum pressure.

Table( 4) : Effect of riser height and emission angles of the spray Pop-Up sprinkler at operating pressure of 3 bar on discharge, coefficient of uniformity, coefficient of variation and water loss percent.

\begin{tabular}{|c|c|c|c|c|c|c|c|c|c|c|}
\hline \multirow{2}{*}{$\begin{array}{l}\text { Riser } \\
\text { height } \\
\mathrm{m}\end{array}$} & \multirow{2}{*}{$\begin{array}{c}\text { Parame- } \\
\text { ters. }\end{array}$} & \multicolumn{9}{|c|}{ Emission angles } \\
\hline & & $45^{\circ}$ & $90^{\circ}$ & $135^{\circ}$ & $180^{\circ}$ & $225^{0}$ & $270^{\circ}$ & $315^{\circ}$ & $360^{\circ}$ & mean \\
\hline \multirow[t]{4}{*}{0.15} & $\mathrm{q}, \mathrm{m}^{3} / \mathrm{h}$ & 0.157 & 0.344 & 0.454 & 0.544 & 0.551 & 0.591 & 0.602 & 0.627 & 0.437 \\
\hline & $\mathrm{Cu} \%$ & 91.67 & 90.85 & 88.01 & 87.85 & 86.36 & 84.85 & 83.36 & 81.53 & 86.81 \\
\hline & $\mathrm{Cv} \%$ & 8.33 & 9.14 & 11.99 & 12.15 & 13.64 & 15.15 & 16.64 & 18.47 & $\mathbf{1 3 . 1 9}$ \\
\hline & L\% & 8.19 & 8.10 & 7.35 & 7.01 & 6.77 & 6.49 & 6.15 & 6.00 & 7.1 \\
\hline \multirow[t]{4}{*}{0.75} & $\mathrm{q}, \mathrm{m}^{3} / \mathrm{h}$ & 0.149 & 0.330 & 0.431 & 0.518 & 0.526 & 0.567 & 0.578 & 0.607 & 0.463 \\
\hline & $\mathrm{Cu} \%$ & 90.20 & 88.18 & 86.42 & 85.01 & 83.43 & 82.07 & 80.05 & 79.23 & 84.00 \\
\hline & $\mathrm{Cv} \%$ & 9.80 & 11.82 & 13.58 & 14.98 & 16.57 & 17.93 & 19.95 & 20.77 & 16.00 \\
\hline & L\% & 12.87 & 12.01 & 11.63 & 11.34 & 11.00 & 10.24 & 9.97 & 9.00 & $\begin{array}{l}11.01 \\
\end{array}$ \\
\hline \multirow[t]{4}{*}{1.25} & $\mathrm{q}, \mathrm{m}^{3} / \mathrm{h}$ & 0.141 & 0.310 & 0.407 & 0.490 & 0.497 & 0.537 & 0.546 & 0.573 & 0.438 \\
\hline & $\mathrm{Cu} \%$ & 89.12 & 86.04 & 84.15 & 83.33 & 81.66 & 80.43 & 78.43 & 77.00 & 82.52 \\
\hline & $\mathrm{Cv} \%$ & 10.88 & 13.96 & 15.85 & 16.67 & 18.34 & 19.57 & 21.57 & 23.00 & 17.48 \\
\hline & L\% & 17.54 & 17.33 & 16.94 & 16.18 & 15.91 & 15.03 & 14.95 & 14.10 & $\overline{16.00}$ \\
\hline
\end{tabular}

Data in Table ( 5) show interaction between 2 bar operating pressure, riser height from $(0.15,0.75$ and $1.25 \mathrm{~m})$ and angles from $45^{\circ}$ to $360^{\circ}$. By increasing angles under all riser heights discharge and coefficient of variation ( $\mathrm{Cv} \%$ ) increase, due to interaction between 2 bar, riser height 0.15 and angle $360^{\circ}$ highest values $0.530 \mathrm{~m}^{3} / \mathrm{h}$ but $360^{\circ}$ and riser height $1.75 \mathrm{~m}$ highest value $34.78 \%$ of coefficient of variation ( $\mathrm{Cv} \%$ ). While lowest value $0.105 \mathrm{~m}^{3} / \mathrm{h}$ due to interaction between 2 bar operating pressure riser height $1.75 \mathrm{~m}$ and angle $45^{\circ}$, lowest value of coefficient of variation ( $\mathrm{Cv} \%$ ) under $45^{\circ}$ and riser height $0.1 \mathrm{~m}$. But coefficient of uniformity $(\mathrm{Cu} \%)$ and water loss percent ( $\mathrm{L} \%$ ) decrease by increase angles with all riser heights.

Results in Table (6) show interaction between 1.5 bare operating pressure, riser height from $(0.15,0.75$ and $1.25 \mathrm{~m})$ and emission angles from $45^{\circ}$ to $360^{\circ}$. By increasing angles under all riser heights discharge and coefficient of variation ( $\mathrm{Cv} \%$ ) increase, due to interaction between 1.5 bar riser height on ground and angle $360^{\circ}$ highest values $0.396 \mathrm{~m}^{3} / \mathrm{h}$ 
Table( 5): Effect of riser height and emission angles of the spray PopUp sprinkler at operating pressure of 2 bar on discharge, coefficient of uniformity, coefficient of variation and water loss percent .

\begin{tabular}{|c|c|c|c|c|c|c|c|c|c|c|}
\hline \multirow{2}{*}{$\begin{array}{l}\text { Riser } \\
\text { height } \\
\mathrm{m}\end{array}$} & \multirow{2}{*}{$\begin{array}{l}\text { Para- } \\
\text { meters }\end{array}$} & \multicolumn{9}{|c|}{ Emission angles } \\
\hline & & $45^{\circ}$ & $90^{\circ}$ & $135^{\circ}$ & $180^{\circ}$ & $225^{\circ}$ & $270^{\circ}$ & $315^{\circ}$ & $360^{\circ}$ & Mean \\
\hline \multirow[t]{4}{*}{0.15} & $\mathrm{q}, \mathrm{m}^{3} / \mathrm{h}$ & 0.124 & 0.251 & 0.343 & 0.365 & 0.378 & 0.485 & 0.512 & 0.530 & 0.274 \\
\hline & $\mathrm{Cu} \%$ & 83.40 & 81.45 & 79.24 & 77.89 & 75.66 & 74.94 & 72.11 & 71.22 & 75.00 \\
\hline & $\mathrm{Cv} \%$ & 16.60 & 18.55 & 20.76 & 22.11 & 24.34 & 25.06 & 27.89 & 28.78 & 25.00 \\
\hline & L\% & 12.06 & 11.90 & 11.37 & 10.98 & 10.21 & 9.85 & 9.26 & 8.15 & 10.50 \\
\hline \multirow[t]{4}{*}{0.75} & $\mathrm{q}, \mathrm{m}^{3} / \mathrm{h}$ & 0.114 & 0.231 & 0.320 & 0.340 & 0.353 & 0.465 & 0.486 & 0.520 & 0.353 \\
\hline & $\mathrm{Cu} \%$ & 79.55 & 77.22 & 75.02 & 73.86 & 72.32 & 73.30 & 70.00 & 68.11 & 73.67 \\
\hline & $\mathrm{Cv} \%$ & 20.45 & 22.78 & 24.98 & 27.68 & 27.68 & 26.70 & 30.00 & 31.89 & 26.33 \\
\hline & $\mathrm{L} \%$ & 19.15 & 18.95 & 17.31 & 17.07 & 16.15 & 13.57 & 11.80 & 9.88 & 15.48 \\
\hline \multirow[t]{4}{*}{1.25} & $\mathrm{q}, \mathrm{m}^{3} / \mathrm{h}$ & 0.105 & 0.215 & 0.310 & 0.330 & 0.345 & 0.451 & 0.476 & 0.510 & 0.343 \\
\hline & $\mathrm{Cu} \%$ & 78.54 & 75.32 & 73.66 & 71.23 & 69.44 & 68.11 & 66.27 & 65.22 & 70.97 \\
\hline & $\mathrm{Cv} \%$ & 25.53 & 24.68 & 26.34 & 28.77 & 30.56 & 31.89 & 33.73 & 34.78 & 29.03 \\
\hline & L\% & 25.53 & 24.56 & 19.90 & 19.51 & 18.05 & 16.17 & 15.61 & 15.61 & 18.62 \\
\hline
\end{tabular}

Table( 6 ): Effect of riser height and emission angles of the Pop-Up sprinkler at operating pressure of 1.5 bar on discharge, coefficient of uniformity, coefficient of variation and water loss percent .

\begin{tabular}{|c|c|c|c|c|c|c|c|c|c|c|}
\hline \multirow{2}{*}{$\begin{array}{l}\text { Riser } \\
\text { height } \\
\mathrm{m}\end{array}$} & \multirow{2}{*}{$\begin{array}{l}\text { Para- } \\
\text { meters } \\
\text {. }\end{array}$} & \multicolumn{9}{|c|}{ Emission angles } \\
\hline & & $45^{\circ}$ & $90^{\circ}$ & $135^{\circ}$ & $180^{\circ}$ & $225^{0}$ & $270^{\circ}$ & $315^{\circ}$ & $360^{\circ}$ & mean \\
\hline \multirow[t]{4}{*}{$0.15 \mathrm{~m}$} & $\mathrm{q}, \mathrm{m}^{3} / \mathrm{h}$ & 0.091 & 0.175 & 0.243 & 0.300 & 0.321 & 0.351 & 0.3876 & 0.396 & 0.283 \\
\hline & $\mathrm{Cu} \%$ & 73.00 & 71.10 & 69.44 & 67.54 & 65.11 & 63.22 & 62.23 & 61.22 & 66.44 \\
\hline & $\mathrm{Cv} \%$ & 27.00 & 28.90 & 30.56 & 32.46 & 34.89 & 36.78 & 37.77 & 39.78 & 33.39 \\
\hline & $\mathrm{L} \%$ & 14.21 & 13.81 & 13.50 & 12.67 & 12.21 & 11.36 & 11.10 & 10.91 & 12.48 \\
\hline \multirow[t]{4}{*}{$0.75 \mathrm{~m}$} & $\mathrm{q}, \mathrm{m}^{3} / \mathrm{h}$ & 0.082 & 0.160 & 0.226 & 0.2825 & 0.301 & 0.329 & 0.3677 & 0.378 & 0.266 \\
\hline & $\mathrm{Cu} \%$ & 70.11 & 68.22 & 67.11 & 66.44 & 65.00 & 63.77 & 61.88 & 60.44 & 65.37 \\
\hline & $\mathrm{Cv} \%$ & 29.89 & 31.78 & 32.89 & 33.56 & 35.00 & 36.30 & 38.14 & 39.56 & 34.63 \\
\hline & $\mathrm{L} \%$ & 22.70 & 21.20 & 19.16 & 18.21 & 17.67 & 16.91 & 15.68 & 14.74 & 18.28 \\
\hline \multirow[t]{4}{*}{$1.25 \mathrm{~m}$} & $\mathrm{q}, \mathrm{m}^{3} / \mathrm{h}$ & 0.077 & 0.149 & 0.215 & 0.2665 & 0.286 & 0.324 & 0.360 & 0.370 & 0.259 \\
\hline & $\mathrm{Cu} \%$ & 68.55 & 66.33 & 64.88 & 62.66 & 60.22 & 58.55 & 57.11 & 56.22 & 61.81 \\
\hline & $\mathrm{Cv} \%$ & 31.45 & 33.67 & 35.12 & 37.34 & 39.78 & 41.45 & 42.89 & 43.78 & 38.19 \\
\hline & L\% & 27.42 & 26.62 & 23.15 & 22.29 & 21.77 & 18.18 & 17.29 & 16.54 & 21.00 \\
\hline
\end{tabular}

and interaction $360^{\circ}$ and riser $1.25 \mathrm{~m} 43.78 \%$ of coefficient of variation $(\mathrm{Cv} \%)$. While lowest value $0.077 \mathrm{~m}^{3} / \mathrm{h}$ due to interaction between $1.5 \mathrm{bar}$ operating pressure riser height $1.75 \mathrm{~m}$ and angle $45^{\circ}$, lowest of coefficient of variation ( $\mathrm{Cv} \%) 27.00 \%$ with angle 45 and riser $0.15 \mathrm{~m}$. But 
coefficient of uniformity $(\mathrm{Cu} \%)$ and percentage of loss ( \%) decrease by increase angles with all riser heights. Results showed that, when emission form is curved, that means, the pressure is too low. So the coefficient of uniformity $\mathrm{Cu} \%$ is low.

\section{CONCLUSION}

The main results in the present work can be summarized as follows.

Due to decreasing pressure, discharge and coefficient of uniformity decrease. While water loss percent due to evaporation and water drift increase.

By increasing riser height with all emission angles discharge and coefficient of uniformity decrease.

By increasing of emission angles from $45^{\circ}$ to $360^{\circ}$, discharge and coefficient of variation increase. While coefficient of uniformity and water loss percent decrease.

Interaction between 3 bar operating pressure, riser height $0.15 \mathrm{~m}$, and angle $45^{\circ}$ gave the highest value of coefficient of uniformity, and lowest value coefficient of variation and water loss percent .

\section{REFERANCE}

Christiansen , J. E. ( 1942). Irrigation by sprinkler . California Agric. Exp. Sta. Bull. 670., 124p Uni. Of California .Brkeley ,California.

El-Awady, M. N. , E. G. Vis. Kumar ., and S. Mitra (2003) Distribution uniformity from Pop-Up sprinkler and Landscape water. The $11^{\text {th }}$ An. Conf. MSAE, Kafer-ElSheikh, Egypt181- 194.

El- Sherbeni , A. M. ( 1994 ) Design of sprinkler and drip irrigation systems in newly reclaimed soils. Unpublished $\mathrm{Ph}$. D.Thesis in Agric. Eng. Fac. of Agric. Zagaz.Uni. Egypt141p.

Irrigation Training and Research Center ITRC ( 1991 ) Landscape water management principles, Version 1.01, Cal poly State University, San Luis Obispo, California: HOP .

Keller , J. , and R. D. Bliesner . ( 1990 ) Sprinkler and Trickle Irrigation New York, N. Y. :Van Nostrand Reinhold. 
King, B. A. and D. C. Kincaid ( 2004 ) A variable flow rate sprinkler for site -specific irrigation management . Applied Eng. In Agric. Of the ASAE20 (6) :765-770.

ZanonE. R., R. Testezlaf , and E. J. Matsura ( 2000) A data acquisition system for sprinkler uniformity testing . Applied Eng. In Agric. Of the ASAE 16 ( 2 ) 123-127.

$$
\text { تقييم أداء الرشاش القفاز ( بوب ـ أب) المبل) }
$$

1.د/ أحمد حسن جمعه ، . ا.د/ عصام الدين واصف و د/ أمال فتوح الثرقاوى

تم اجر اء هذه الدراسة فى كلبة الزر اعة جامعة المنوفية لدراسة تاثثير كلا من زاوية الانبعاث

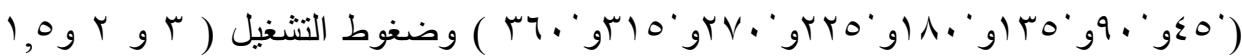

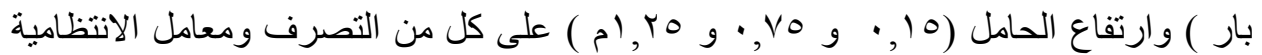
ومعامل الاختلاف وكذلك نسبة فاقد المياه نتيجة البخر نتح وتأثير الرياح و اظهرت النها النتائج أن.

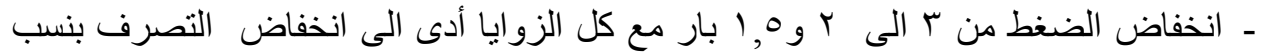

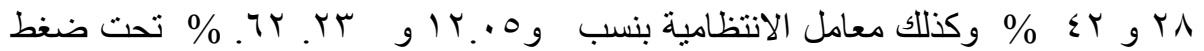

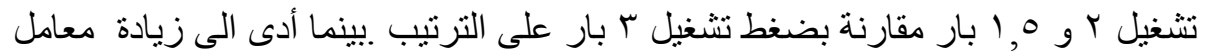

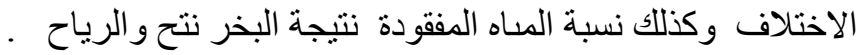

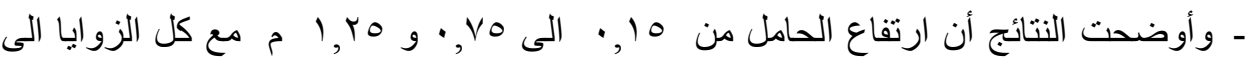

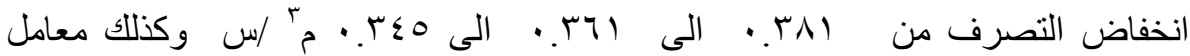

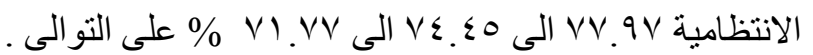

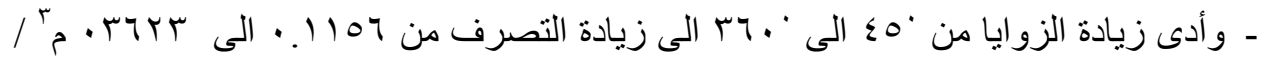

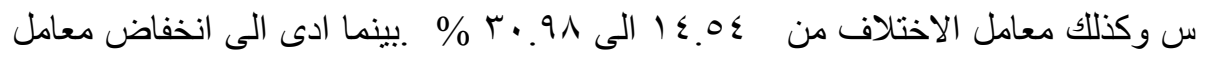

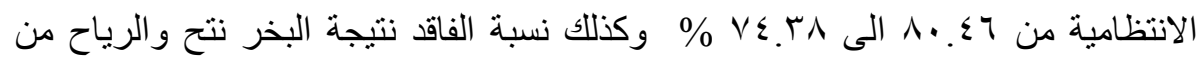

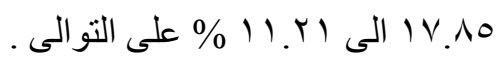

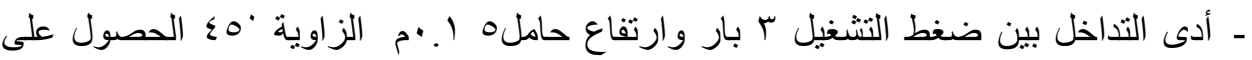

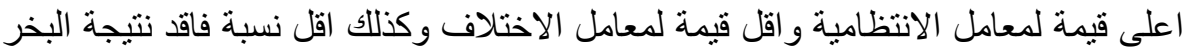

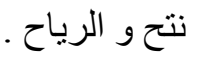

